\title{
Cécile Michel
}

\section{What about 3D Manuscripts? The Case of the Cuneiform Clay Tablets}

\begin{abstract}
Cuneiform writing has been used for more than three millennia in a vast area from the Mediterranean Sea to Iran, and from the Black Sea to Egypt (El Amarna). There, different cuneiform writing systems have been used by various populations speaking different languages. Cuneiform signs were imprinted on clay, on wood or ivory tablets covered with wax, or engraved on stone and metal. But the great majority of the recovered texts were written on unfired clay tablets. Up to now, ancient Near Eastern archaeologists have unearthed more than a million of original cuneiform texts which are deciphered and studied since the middle of the nineteenth century by Assyriologists. Traditionally, these scholars use to call themselves epigraphists, but when mentioning their source material, they usually speak about manuscripts. In order to understand this paradox, this contribution analyses the various characteristics of clay as a writing medium.
\end{abstract}

\section{Introduction}

The distinction between manuscripts and epigraphy traditionally comes from historians of the classical world who study writing on soft, perishable media, which have often been lost, except when repeatedly copied or when copied onto hard and durable media that could survive the vagaries of time. Thus, according

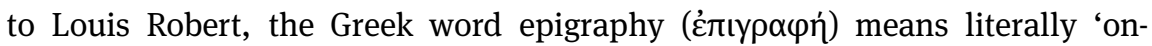
writing, inscription' and refers to the study of ancient epigraphs or inscriptions, usually short, and engraved, incised, or painted on durable media: stone, metal, wood, clay, etc. ${ }^{1}$ The person who studies inscriptions is called an 'epigrapher'.

The website of the CNRS National Centre of Textual and Lexical Resources ${ }^{2}$ provides the following definition of the word 'epigraphy', which applies to the Greek and Latin worlds, and thus to classical Antiquity: 'An auxiliary historical

1 Robert 1961.

2 'The purpose of the lexical portal is to federate, enhance and share, as a priority with the scientific community, a set of data resulting from research work on lexicons' <https://www.cnrtl.fr/> (accessed on 12 Sept. 2020). 
science that studies inscriptions (including epigraphs), which are usually ancient and engraved or sometimes painted on durable media'. ${ }^{3}$ On the same website, the word 'manuscript', which comes from the Latin manu scriptus and literally means 'written by hand', is defined as follows: 'A work written or copied by hand [...] The original version of a work written by hand [...] A manuscript on paper, papyrus, parchment, vellum; a manuscript with illuminations, with miniatures. ${ }^{34}$ A manuscript, then, can exist in various formats (e.g. scrolls, codex), and can be illustrated with pictures or marginal decorations (illuminated manuscripts). Because it is produced by hand, a manuscript is a unique object. Even if two manuscripts contain a similar text, they will never be identical: there might be differences in their format, ink colour, media, number of lines per page, annotations, or style of writing. The person who studies the text and writing of manuscripts is called a 'palaeographer'; the person who studies the book manuscript as a material object works in the field of codicology.

How can one apply such definitions to cuneiform artefacts? ${ }^{5}$ Cuneiform writing was used in the Near East and the Middle East for more than three millennia (3400 BCE - $75 \mathrm{CE}$ ); there were three different systems, which used classifiers and logograms, syllabograms, or letters, to express a dozen different languages. Cuneiform signs, made of wedges, were shaped in the negative, in three dimensions, with a stylus impressed into fresh clay, or onto wooden tablets covered with wax, or they were engraved on stone or metal. Of the more than

3 <https://www.cnrtl.fr/definition/\%C3\%A9pigraphie> (accessed on 12 Sept. 2020): 'Science auxiliaire de l'histoire ayant pour objet l'étude des inscriptions (parmi lesquelles les épigraphes), généralement anciennes, gravées ou parfois peintes sur des supports durables'.

4 <https://www.cnrtl.fr/definition/manuscrit> (accessed on 12 Sept. 2020): 'Ouvrage écrit ou copié à la main [...] Version originale d'une œuvre, écrite à la main [...] Manuscrit sur papier, sur papyrus, sur parchemin, sur vélin; manuscrit à enluminures, à miniatures.'

5 This contribution originated as a keynote introductory paper delivered at the conference 'Manuscripts and Epigraphy', organized by the Centre for the Study of Manuscript Cultures (CSMC) in November 2013. The idea of the conference was to consider whether there is a significant differentiation between manuscripts and epigraphy and to determine what exactly these differences are. Michael Friedrich, director of the Centre, therefore invited me to explain how the material I was studying - clay tablets covered with cuneiform signs - combined elements from both categories. This exciting conference was the beginning of my Hamburg adventure. I fell, quite willingly, into the 'trap' set by Michael, which sealed our unfailing friendship. I am particularly happy to dedicate this article as a token of friendship to Michael Friedrich, a great and wonderful scholar who has built a community of researchers united around written artefacts of the world, past and present. He had been asking for this contribution for several years because the inclusion of 3D cuneiform clay tablets in the manuscript category led the researchers of the CSMC to propose a new definition for the word 'manuscript' (Lorusso et al. 2015). I hope that this modest contribution will meet his expectations. 
one million cuneiform texts discovered to date, the great majority were written on unbaked clay tablets.

Because of this medium, the cuneiform tablets are difficult to fit into the traditional categories of written artefacts. The tablets have been, and still are, regularly classified as epigraphic study material, but they exhibit many of the characteristics of manuscripts, and palaeographic studies have increased in recent years. The present contribution discusses the nature of cuneiform artefacts, and more specifically clay tablets, with a view to ascertaining whether they fit into this traditional classification. First we shall consider the characteristics of clay as a medium for writing, then the interaction between the medium and its content, i.e. text and eventually images, and finally the organisation of cuneiform clay tablets in archives and libraries.

\section{The use of clay as a material support for writing cuneiform}

Clay, abundant in Mesopotamia, was used for multiple purposes, such as bricks for various constructions, pottery for daily life, and as a material support for writing cuneiform. The use of clay for writing purposes has many advantages, including its durability, the potential for recycling tablets for subsequent use, ease of transport, and the possibility of reproducing short text on bricks and other objects by stamping.

\subsection{Writing cuneiform on clay tablets}

If we consider the mass of cuneiform artefacts unearthed to date, perhaps between 80 and 90 per cent of them consist of unbaked clay artefacts, predominantly tablets. It is impossible to evaluate the quantity of texts written on perishable media. The shape of the cuneiform clay tablet depends on the text it carries; it may be lenticular, square, or rectangular. Tablets have various sizes, from very small texts with very few lines to large ones with several columns and many lines or boxes containing words or sentences (Fig. 1). ${ }^{6}$ The choice of the format depended on the nature of the text, the period, and the language used. ${ }^{7}$

6 Lion and Michel 2016, 30-31; Frahm and Wagensonner 2019.

7 André-Leicknam and Ziegler 1982, 73-116, 171-262; Walker 1987; Finkel and Taylor 2015. 


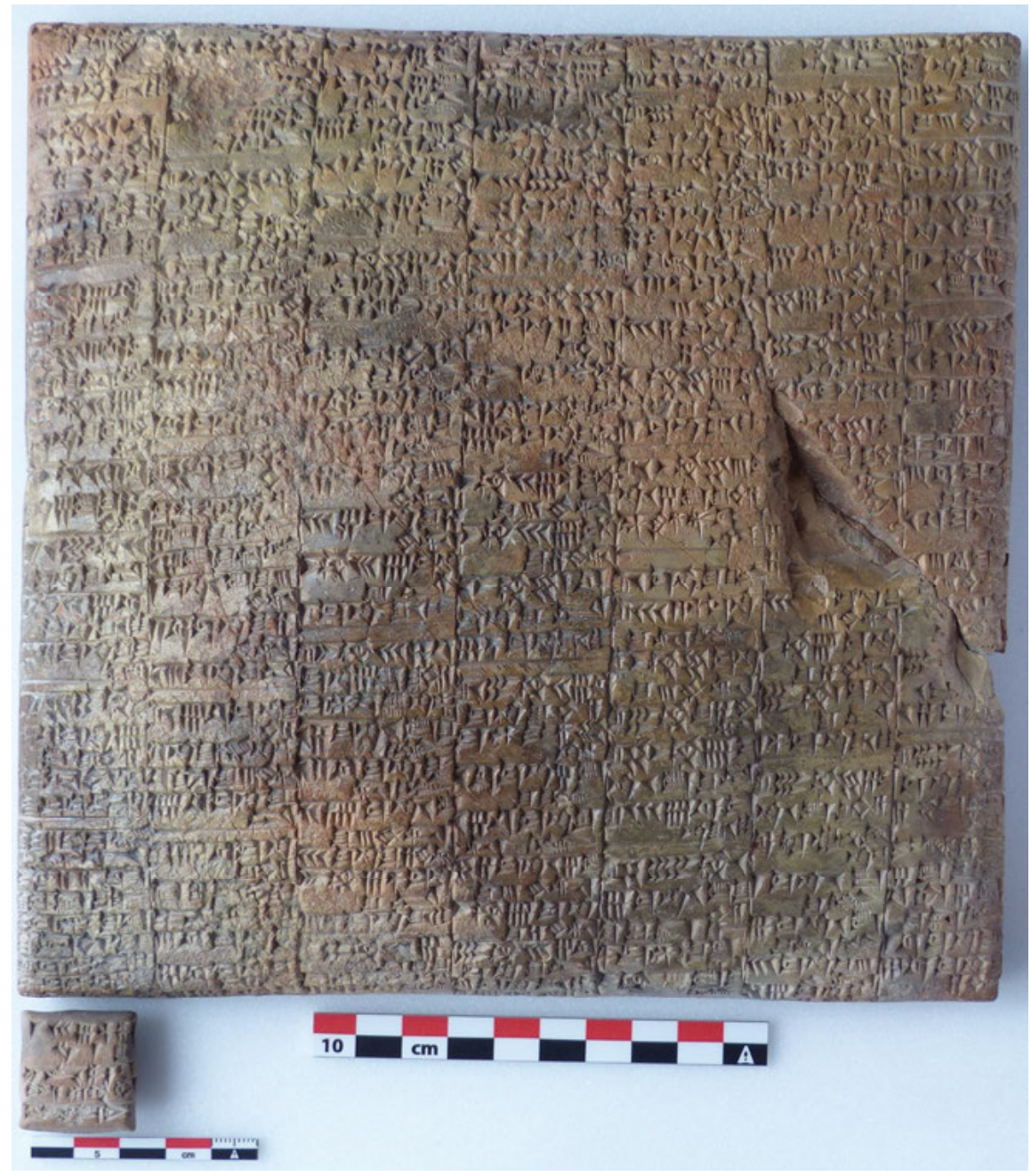

Fig. 1: Two tablets from Ur III (twenty-first century BCE). Musée du Louvre, AO 2681, Girsu, and the small AO 19735, Umma. Photo: Cécile Michel.

First the scribe had to prepare the tablet, shaping its size according to the text that would be written upon it. The clay may or may not have been specially prepared. Levigation produces a fine, pure clay; the scribe prepared a core of clay and covered it with a thin layer of this pure clay. The presence of shell 
fragments or plant remains in some tablets shows that tablets could also be made from unprocessed clay. ${ }^{8}$ In some instances, tablets are shaped in one block, without any additional layer. ${ }^{9}$ The text was written in lines from left to right, often parallel to the smallest side, and in one column (Fig. 2). Ruling may separate the lines of text, and the signs would be written as if hanging from these lines. The scribe wrote with a reed cut at an angle, having a square crosssection, and used one angle to imprint fresh clay; the result was a wedgeshaped impression that appeared in the negative. Depending on the pressure he gave to the stylus, the impression was more or less long and deep.

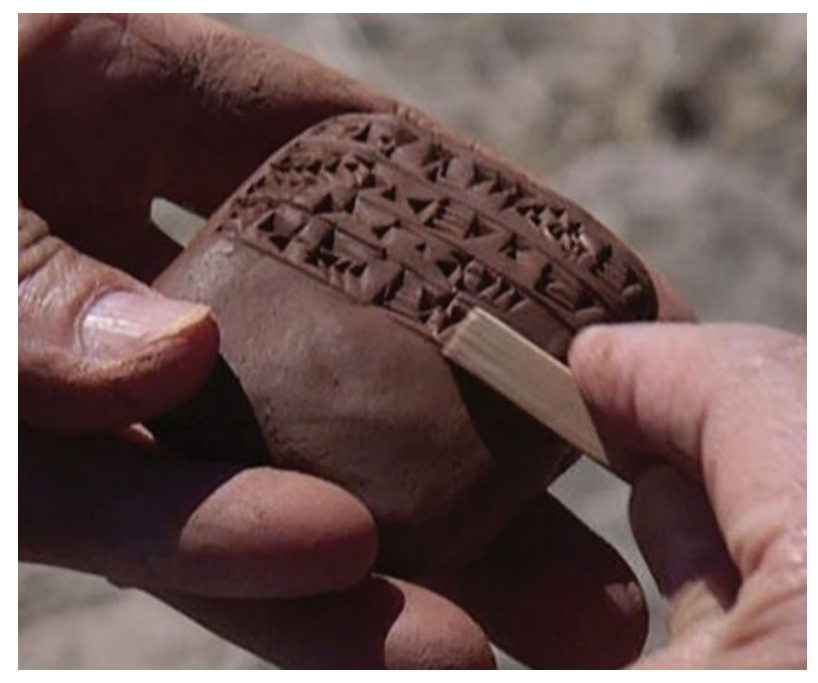

Fig. 2: The author writing cuneiform on fresh clay. Photo: Vanessa Tubiana-Brun.

Appearing on various materials, cuneiform was almost always written in three dimensions. There are few exceptions with two dimensional cuneiform signs, such as short texts found on painted and glazed wall plaques that decorated the temple of the goddess Ištar at Nimrud (ancient Kalhu). ${ }^{10}$ Since the decipherment of cuneiform writing in the nineteenth century, modern-day Assyriologists draw cuneiform signs on a soft medium - paper - and in two dimensions, trying to

8 Cartright and Taylor 2011.

9 This is, for example, the case with Old Assyrian tablets, which do not reveal a core when broken.

10 Albenda 1991, 46. 
reproduce the ancient texts. ${ }^{11}$ The cuneiform script, however, does not adapt well to two dimensions: it takes much more time to draw a cuneiform sign on paper than to imprint it on fresh clay with a reed stylus. A single stroke is sufficient to form a wedge in clay; drawing a wedge with ink on paper takes three strokes, the three sides of the triangular head of the wedge.

Tablets were written in a specific order: obverse, lower edge, reverse, upper edge, and even sometimes left edge, thus rotating along a horizontal axis, contrary to our piece of paper, which we flip along the vertical axis. The right edge of a tablet is occupied by the last signs of long lines, continued onto the edge. The scribe had to write the text in one go because clay dries out. It is possible, however, to keep a tablet fresh for some hours by wrapping it in a wet tissue. ${ }^{12}$

\subsection{Durability of the medium}

Clay was used daily to shape tablets for the administration of large institutions or for private purposes. In a diplomatic letter found at Mari (Middle Euphrates, eighteenth century BCE), the king of the city of Ašnakkum wrote to the king of Mari: 'I have exhausted all the clay of Ašnakkum for the letters that I repeatedly send! ${ }^{13}$ The same figurative image can be found in a letter sent by a private merchant of Kaneš (Central Anatolia, nineteenth century BCE) to a colleague: 'How is it (...) that I have exhausted all the clay of this town by repeatedly sending you letters, and that you, you do not send me silver, and that I never hear anything from you? ${ }^{14}$

Clay exhibits plasticity when mixed with water; when dry, it becomes firm, and when fired in a kiln, permanent physical and chemical changes convert it into a ceramic material. ${ }^{15}$ The durability of clay is then real. Most of the time, however, cuneiform clay tablets in antiquity were not fired but only dried in the

11 See, for example, the series published by the Louvre, Textes Cunéiformes Musée du Louvre, or by the British Museum, Cuneiform Texts from Babylonian Tablets in the British Museum.

12 For the inauguration of the Maison d'Initiation et Sensibilisation aux Sciences (ParisSaclay) in 2017, I wrote on a large (20 cm in length) foundation tablet which I had prepared early in the morning. I kept it in a wet tissue for four hours so that the officials could add a sign to complete their name, which they did on the still-fresh clay. For a photo of the tablet: $<$ http://hebergement.u-psud.fr/miss/miss_dir/wp-content/uploads/2018/07/P_20180712_112825 bis.jpg $>$ (accessed on 10 Sept. 2020).

13 Kupper 1998, no. 105:10.

14 Kt 89/k 232, Michel 2018, 52, n. 8.

15 Faivre 1995. 
sun. ${ }^{16}$ This means that tablets vanished from places that were flooded. Julian Reade also notes the damages inflicted by salt:

An unfired tablet usually becomes damp in the soil; it may be permeated by soluble salts from the groundwater, and salts may crystallise on its surface as a more or less solid layer. After excavation a tablet again dries and the clay hardens. If the tablet is made of highquality clay and is not badly affected by salt or a damp atmosphere, it may remain solid; otherwise residual salts in the clay may migrate to the surface and cause fresh damage. ${ }^{17}$

In general, unbaked clay tablets have survived until today, as opposed to other writing media made of organic materials. The fire that destroyed many sites baked some of the tablets, thus aiding their preservation. This is the case, for example, with Aššurbanipal's palace at Nineveh, which included his huge libraries; when fire devastated the royal palace in 612 BCE, many clay tablets were completely or partially baked. ${ }^{18}$ But wooden tablets covered with wax, ${ }^{19}$ papyri, and texts on leather all disappeared.

The durability of clay is therefore also relative; unfired clay is durable compared to soft writing materials, but less durable than fired clay. The ancient Mesopotamians were aware of these characteristics and intentionally baked tablets that they intended to preserve. Among these baked tablets are some literary and mythological pieces kept in first-millennium palace and temple libraries, or important royal inscriptions. For example, the Tiglath-pileser III (745-727) foundation tablet or the report of the eighth campaign of the Assyrian king Sargon II (721-705) were both fired in a kiln after being dried. ${ }^{20}$ This was also the case with some title-deeds recording purchases and found in a private Neo-Babylonian archive at Uruk. Such documents were used as proof of ownership and were thus transmitted from buyers to buyers over several generations. ${ }^{21}$

16 This was already noted by Chiera 1938, 17.

17 Reade 2017, 73-74.

18 Cartright and Taylor 2011, 68.

19 Wooden tablets are attested at least from the third millennium on. We know that following the request of Assurbanipal to gather all important texts for his palace library, people from Borsippa sent many writing boards inscribed with literary texts; see Fincke 2004, 126-129, among others.

20 Tiglath-pileser III foundation tablet K 3751 (Tadmor and Yamada 2011, 117); Sargon II $8^{\text {th }}$ campaign (Thureau-Dangin 1912). Both tablets exhibit 'drying/firing holes' which could have been made to facilitate the evaporation of the water from the core of the tablet. However, because they appear on the edges of the first tablet and are distributed regularly on the obverse and reverse of the second tablet, the holes might not have the same use; see Reade 2017, 178179. There is a debate concerning the purpose of these small holes.

21 Hunger 1970, 197. 


\subsection{A material easy to recycle}

Cuneiform clay tablets could be recycled in different ways or erased. ${ }^{22}$ School exercises produced by apprentice scribes, for instance, were not intended for archiving. At the beginning of the curriculum, the student learned how to write signs and copied lists of words, as well as metrological and numerical tables; then he or she wrote small texts in Sumerian and solved computing exercises. These exercises were written on quadrangular or lenticular tablets. Once an exercise was finished, and corrected by the master, the clay of the tablet could be moistened and shaped again into a new tablet. ${ }^{23}$ It is not impossible that some administrative drafts underwent the same treatment. In the Mari palace, one or two administrative tablets were found destroyed, squeezed in someone's hand, presumably shortly after being written. ${ }^{24}$ The text of a letter found at Tell Bi'a, ancient Tuttul, was erased by applying an additional layer of clay. ${ }^{25}$

Tablets were not always recycled as media for new texts: some groups of school texts were reused as fill in buildings and inserted into mud brick walls. Nippur, a cultural centre of Lower Mesopotamia, has provided one of the best examples of this phenomenon: more than 1400 school texts were found in 'House F', recycled as building material in the floor of some rooms as well as in a large clay chest built in the courtyard. ${ }^{26}$

\subsection{A transportable medium}

When not recycled, clay tablets were small enough to be easily moved and transported; this is especially true for the texts that had an immediate utilitarian purpose, those traditionally referred to by Assyriologists as 'practical texts' or 'texts of practice'. ${ }^{27}$ This modern category includes among others, legal texts and letters.

22 See below, Section 3.4, and Faivre 1995.

23 Taylor and Cartwright 2011, 318, suggest that the extent of recycling has been overestimated by Assyriologists, given that raw clay was abundant in Mesopotamia and usable as a writing medium even without preparation.

24 Villard 1984, 585, no. 627 has been smashed, and only a personal name is still visible; Charpin 2008, 102, Fig. 17, shows a photo of such an administrative tablet, which could have been in the process of being recycled.

25 Krebernik 2001, no. 378, photo pl. 63.

26 Robson 2001, 40-45.

27 See below, Section 3.1. 
Such letters are varied in nature; they can be private, administrative, or diplomatic, and they facilitate communication between people that cannot communicate orally. Depending on place and time, some sites of the ancient Near East have yielded many letters written on clay. ${ }^{28}$ In the archives of Assyrian merchants that were discovered in Central Anatolia and date to the nineteenth century BCE, letters form the most representative genre of texts. Such an important number of letters may be explained by the geographical dispersion of the merchant family members: men left their wives and young children in Aššur (on the Tigris, modern Iraq) to trade a thousand kilometres away from home and settled there in different towns. These Assyrians and their relatives exchanged hundreds of letters each year, many of which have been and continue to be found in the houses of their recipients in Anatolia. ${ }^{29}$ As they are written to be sent, clay letters are usually rather small, not exceeding the size of the palm, which makes them easily transportable. Indeed, large tablets are more fragile and may break during transport.

The size of the tablet varies a great deal, depending of the length of the message that the writer wanted to send to the addressee. Some tablets are very small, containing only four lines, while others may bear up to sixty, or even a hundred lines. Although their size is usually adapted to the length of the text, that is not always the case. Thus some letters from the chancellery of King RîmSîn of Larsa (1822-1763) are oversized, perhaps because they were dictated to a scribe who did not know in advance the length of the text. ${ }^{30}$ Neo-Assyrian letters often present a fixed size. ${ }^{31}$ By contrast, some Old Assyrian letters (nineteenth century BCE) were not big enough, so a small, flat second 'page' was added to the first tablet. The Assyrian merchants referred to this post scriptum as a sibat tuppim ('additional tablet'); it was banded together with the main tablet inside the envelope (Fig. 3).

Letters, as well as contracts, were enclosed inside clay envelopes (Fig. 3). ${ }^{32}$ The oldest envelopes discovered are contract envelopes; envelopes for letters appear only at the end of the third millennium and were sometimes used for letter-orders. Once the tablet was dried in the sun, it was covered by a thin layer of clay, which formed the envelope. This envelope protected the confidential character of the letter, but also protected its integrity during transport. The

28 Michalowski 2011.

29 Michel 2001, 2008.

30 Charpin 2002, 489.

31 Radner 1995, 72.

32 Bérenger 2018; Michel 2020a. 
sender rolled a personal cylinder seal on the envelope of the letter and wrote his or her own name and the name of the recipient. Letters in their envelopes were then carefully wrapped in textiles, reeds, or leather and carried by special messengers, or they were loaded on pack donkeys with other goods. When the letter reached its destination, the recipient broke the envelope to read the letter.

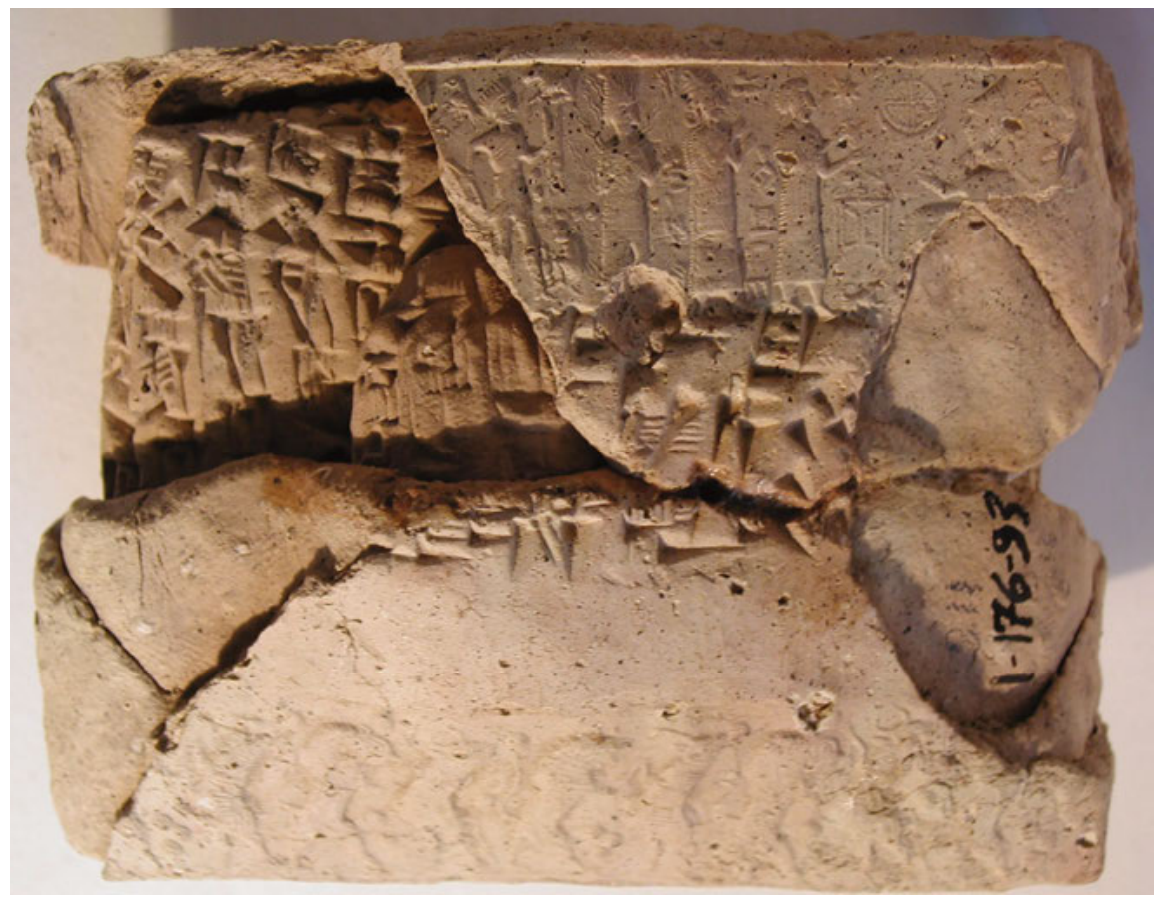

Fig. 3: A letter written on a tablet, with a small 'second page' covered by its partly broken envelope (Kt 93/k 211). Kültepe, nineteenth century BCE. Photo: Cécile Michel. @ Kültepe Archaeological Mission.

Envelopes of contracts bear an abstract or the complete text of the contract as well as the seal imprints of the parties involved, including the witnesses; this gave legal value to the contract. When the sealed envelope was broken, the document was no longer valid. 


\subsection{Hand copied tablets and stamped bricks}

Copying texts was a very common practice in Ancient Mesopotamia. ${ }^{33}$ During the first years of the curriculum in the early second millennium, students had to copy various types of texts and memorize their content: lists of signs, syllabaries, lexical lists, proverbs, contract models, but also metrological lists and tables, as well as several numerical lists. Further in the curriculum, they copied long literary texts that might occupy several tablets. ${ }^{34}$ The palace scribes sometimes made several copies of royal inscriptions: for example, a large number of clay cones and nails were inscribed under Gudea of Lagaš in celebration of a religious action of the king; many of these commemorate the construction of a temple for the god Ningirsu. ${ }^{35}$ Scribes could also be asked to make several copies of a royal letter to be sent to provincial governors.

Copies of tablets are also found in private archives, as we learn from clay labels attached to various tablet containers. ${ }^{36}$ Legal texts were usually certified by witnesses; each of the parties and even some of the witnesses could receive a copy of the contract, which they then kept in their own archives. Some official letters were sent in multiple copies to the different persons concerned ${ }^{37}$ Likewise, private letters could be sent simultaneously to several addressees who would each receive a copy, and some senders could decide to make copies of some of their own letters for their personal archives. ${ }^{38}$

All these duplicates were made by hand, but copies of short texts could also be made by stamping. The king could, for example, order the stamping of a text on bricks to commemorate the construction of temples, palaces, or city walls. Inscribed bricks exist throughout the three millennia of cuneiform writing. The short written text contains the name and titulature of the king along with an indication of the construction work. The inscribed clay matrix, written in mirror reverse and in relief, was prepared with a mould. The bricks were thus inscribed before drying and were incorporated into the building, the inscription being visible or not. ${ }^{39}$

Stamp seals and cylinder seals were also imprinted on clay. The cylinder seals could bear a few lines of cuneiform signs, with, for example, the name of

33 Michel 2020b.

34 Veldhuis 1997, Proust 2007, Robson 2009.

35 Edzard 1997, 109-166, lists more than 2,000 such objects.

36 Özgüç and Tunca 2001, 275 (Kt c/k 834), 300 (94/k 878); Michel 2008.

37 Veenhof 2003, 434-435.

38 Michel 2018, 53, n. 10.

39 Sauvage 1998, 38-40. 
the owner of the seal. Rolling a cylinder seal on clay was the quick, standard way to 'sign' a document. ${ }^{40}$

\section{The text and its medium}

There are many aspects of the interaction between text and medium. Here we will be concerned only with those aspects that may bring some light on the qualification of clay tablets as either manuscripts or inscriptions, aspects such as the relationship between text and image, the possibility of deleting or adding text, and series of tablets considered as 'books'.

Beside clay, cuneiform signs could also be written on stone, metal, or wooden tablets covered with wax. The choice of medium depended not only on the nature, content, and purpose of the text, but also on its author and addressee. For example, royal inscriptions and dedicatory texts for the gods were inscribed on precious and durable supports such as obsidian, semi-precious stones, gold, and silver, while administrative and school texts, which were not intended to be preserved in the long term, were written on unfired clay. ${ }^{41}$ The same phenomenon may be observed in ancient Egypt, where fragments of pots, called ostraca, were used to write letters, daily accounts, or administrative texts in demotic from the seventh century BCE on, while papyrus was used for religious or scholarly works.

\subsection{What medium for what text?}

Assyriologists often classify cuneiform sources according to various categories. The wiki of the Cuneiform Digital Library Initiative proposes four main categories, which are modern and not based on how those who produced the texts could possibly have viewed them. ${ }^{42}$ Three of these categories almost exclusively concern texts written on clay or wooden tablets (or later on flexible media), while the last category includes texts written on various media.

40 Gibson and Biggs 1977.

41 Practical, scholarly, and literary cuneiform texts were also regularly written on wood. See above, n. 19 and below, Section 3.1.

42 CDLI wiki: <http://cdli.ox.ac.uk/wiki/doku.php?id=text_typologies> (accessed on 13 Sept. 2020); proposed and used by today's scholars, this classification of cuneiform texts is modern and artificial. 
The first three categories are practical, scholarly, and literary texts. The practical texts, the most numerous, were written for immediate, utilitarian purposes and document economic and daily activities (letters, legal texts, receipts, accounts, etc.). The scholarly sources include materials written in an educational context: lists of signs, lexical, metrological, or numerical lists, as well as texts concerning mathematics, medicine, astronomy, divination, etc. The literary texts include narrative, mythological, and historical compositions, praise poetry, literary letters, and wisdom literature.

In contrast to the aforementioned written sources, there are also official and display texts, which include royal inscriptions, law collections and treaties, and votive texts; such texts were written on a wide variety of surfaces, materials, and shapes. Produced mainly at the initiative of the ruler and linked to the exercise of royal power, it was important that these texts survive over a long period of time. Triumphal inscriptions were written on stele, statues, reliefs, or clay prisms; they were intended to be visible and read by literate people, while foundation inscriptions, often written on precious materials, stone, or metal, were hidden in the masonry of temples dedicated to gods and were in theory readable only by the gods themselves and perhaps by later kings.

\subsection{Clay and leather during the first millennium BCE}

During the first millennium BCE, Aramaic became the most common language throughout the ancient Near East, and the use of soft and flexible media increased. Several Neo-Assyrian reliefs and paintings show a pair of scribes, one writing cuneiform with a stylus on a tablet or a writing board covered with wax, the second using the Aramaic alphabet to write with ink on a flexible medium, such as a papyrus or leather scroll..$^{43}$ These texts have disappeared: their existence is known from surviving clay sealings that contain a few words describing their content.

During the Hellenistic period (331-141 BCE) in the temples of Uruk and Babylon, scribes used different types of media for writing: clay tablets for cuneiform, wooden tablets covered with wax for Sumerian and Akkadian written with cuneiform signs, as well as alphabetic Aramaic, and Greek; leather and papyri were also used for Aramaic and Greek. The bulk of the documentation was written in Aramaic or Greek on perishable organic media, wooden tablets, or leather. Cuneiform tablets, however, are the only written artefacts that have survived

43 Lion and Michel 2016, 35-36. 
to this day; they were written by the tupšarrū, that is, by scribes belonging to the old urban notability of Babylonia, called Chaldeans by the Greeks. ${ }^{44}$ They were scholars, priests, and temple administrators, all guardians of cuneiform culture in Hellenistic Uruk.

The cuneiform texts document another type of scribes, the sepirū, known from the seventh century onwards, who wrote in Aramaic on leather scrolls. They wrote some of the legal texts that needed to be understood by the local authorities, but clay was also still used for legal purposes. In some cuneiform legal texts, the scribe specified that these were copies made from an original written on leather. ${ }^{45}$ Clay tablets suited administrative practices; they were sealed on the edges, and the text could be very easily checked. And in fact, a significant portion of temple administration is documented by cuneiform tablets.

\subsection{Text and image}

The combination of cuneiform text and images primarily occurs in stone media. During the Neo-Assyrian Empire, large iconographic programmes were executed on palace walls; over hundreds of meters, these programmes show the great achievements of the king, with a substantial amount of detail. ${ }^{46} \mathrm{Clay}$, however, could also bear drawings. ${ }^{47}$

Drawings on clay could be produced with the help of a matrix, such as cylinder seals engraved with miniature figurative scenes that were rolled onto the clay, leaving the imprint of their drawings, which were often accompanied by a few lines of cuneiform signs. ${ }^{48}$

Some clay tablets from the fourth millennium on also show plans and maps. Field surveyors provided schematic representations of rural parcels on clay tablets. ${ }^{49}$ The shape of a field may also be found with other geometrical shapes

44 Oelsner 2003, Jursa 2005, Clancier 2011.

45 Clancier 2005.

46 This is, for example, the case with the iconographic programmes on the walls of Aššurnașirpal II’s (883-859) palace at Kalhu; see Winter 1983, and on Aššurbanipal’s (668-627) palace at Nineveh, Barnett 1976.

47 Clay, as medium for cuneiform, could also take a great variety of shapes. It could be fashioned into the form of an object, such as a sheep liver, which was an organ of thought and feeling, and thus of interest to the diviner. Deformities or anomalies of the liver were reproduced on a clay model, on which was also written a corresponding omen. Such liver models were used as aide-mémoires for priests, or for teaching (Koch-Westenholz 2000).

48 See above, Section 2.6.

49 Liverani 1996. 
as part of a mathematical problem..$^{50}$ Scribes left plans of buildings, some of them showing tiny details such as the brick pavement of an open court or the variation of the thickness of some walls. ${ }^{51}$ There are also maps of cities and geographical areas drawn on clay for religious or military purposes. One of the earliest representations comes from the area of Nuzi, east of the Tigris, and is dated to around 2300 BCE. ${ }^{52}$ The Mappa mundi or Babylonian map of the world, presumably made around the ninth century BCE, is known from a copy of the seventh century. It represents the earth as a disc surrounded by an ocean; Babylon lies in the centre, crossed by the Euphrates. Text on the reverse of the tablet comments on the map. ${ }^{53}$

All these examples demonstrate that, even if it is more awkward to draw curved lines than straight wedges on fresh clay (see Fig. 4), the difficulty did not prevent scribes from drawing on clay tablets, and the drawing was usually accompanied by some cuneiform writing.

\subsection{Erasing and annotating texts on clay}

When carving an inscription in stone, error is irreparable, unless the carver starts anew. When writing a text on fresh clay, it is always possible to erase signs or a line by running a finger across it to smooth out the clay and by writing there once again. ${ }^{54}$ But when clay tablets have been dried in the sun, they become as hard as stone. It is still possible, however, to erase signs or a sentence by watering the clay in order to obtain a flexible surface for rewriting. This possibility, rarely implemented, is documented by a letter that an Assyrian merchant addressed to his representative, ordering him to erase few lines on a document preserved in his archives:

There is a tablet mentioning that the anonymous creditor has loaned 21 minas and 10 shekels of silver to Šalim-Aššur, Ikūnum, and Sabazia, and that concerning this silver, we are jointly responsible. Take out this tablet, read it carefully and where it is written: 'The

50 Friberg 2007, 189-229.

51 Heinrich and Seidl 1967, 41.

52 Meek 1935, no. 1, for a photo <https://cdli.ucla.edu/dl/photo/P213268.jpg> (accessed on 25 Sept. 2020).

53 Horowitz 1988.

54 See, for example, the photo of a partly erased tablet in Robson 2001, 46, Fig. 9. 
silver has been taken in the name of Iliš-tikal' moisten it with water (and erase it) and show to the son of Šalim-Aššur what is important for you. ${ }^{55}$

The addition of annotations, glosses, or marginal numbers to cuneiform tablets is also attested (Fig. 4). Religious, literary, or divinatory texts could be the subject of commentary by scholars who interpreted them via plays on words, by noting meanings on different levels, or by multiplying the possible readings of a text. These commentaries were written on separate tablets referring to the relevant composition. But they could also be inserted as glosses between the lines on copies of the text; they were then written at the same time that the copy was made. ${ }^{56}$ In small characters, between the lines, we find such glosses on astrological series used by scholars working for Aššurbanipal, who was an educated king; these glosses were addressed to the king, who was then able to discuss these matters with his astrologers. ${ }^{57}$

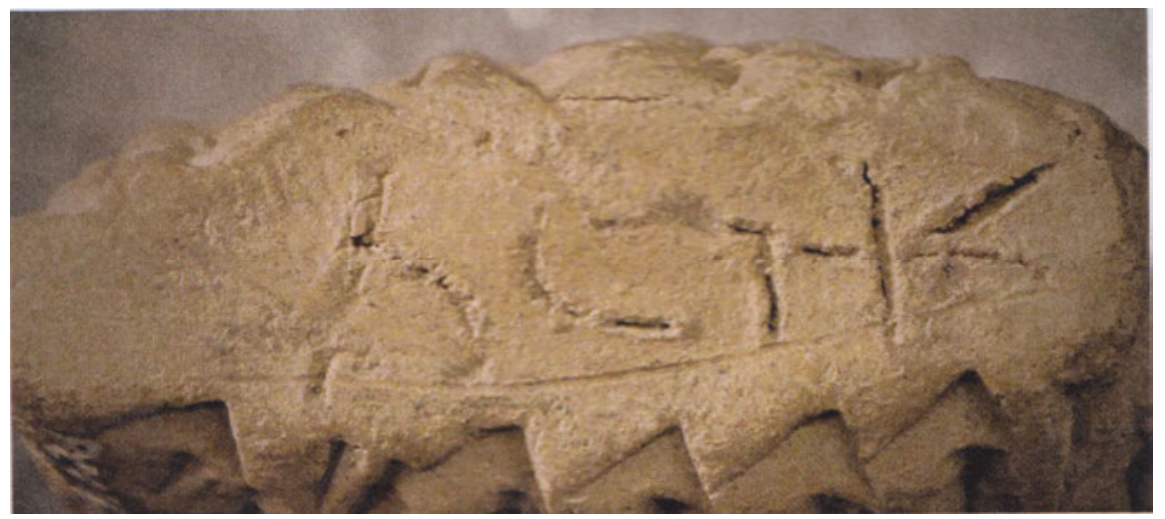

Fig. 4: Aramaic text on the left edge of a tablet with a Neo-Babylonian cuneiform text, from Still and Sonnevelt 2020, 105. Text from the Royal Ontario Museum, Toronto, 521 BCE.

There are other types of annotations, such as he-pi ('broken'), which occurs on a scribe's copy when a portion of the original text was damaged and illegible. Annotations are quite ancient; they go back to the second half of the third millennium BCE in the administrative documentation, where we sometimes find

55 Michel 1995, 25-26.

56 Frahm 2011, 16-17.

57 Villard 1997. Such annotations concern, for example, the translation into Akkadian of a Sumerian logogram, or an indication of how to pronounce it. 
marginal numbers that were supposed to help the scribes in their computations. ${ }^{58}$ All these annotations were written on fresh clay at the same time as the main text, presumably by the scribe who wrote the tablet. There are also a few cases where signs have been scratched onto a dry tablet. ${ }^{59}$

\subsection{Series of tablets, precursors of books}

Literary, divinatory, or mathematical texts could be quite long and needed to be written over several tablets. Each of these contained a colophon that indicated its place in the series. ${ }^{60}$ This colophon was written in a specific space that was left blank on purpose at the end of the tablet. The colophon included various items of information such as the title of the series - corresponding to the incipit of the first tablet - the number of the tablet within the series, or (for literary tablets) the first line of the next tablet within the series, sometimes the date when the copy was made, and rarely the place where it was copied or the origin of the original. First-millennium scribes could even specify the material on which the original was written, such as a clay tablet, a wooden tablet, or a flexible medium.

As an example, the series Enūma Anu Enlil ('When [the gods] Anu and Enlil') contained at least seventy tablets gathering seven thousand astrological omens that referred to the king and the land, and that derived from observation of the moon, the sun, eclipses, Venus, and atmospheric phenomena. ${ }^{61}$ The series was compiled by Esagil-kîn-apla during the eleventh century BCE, and we have several copies from later periods.

Some long literary texts could also be written over several tablets forming a series. The most famous example is the Gilgameš Epic. ${ }^{62}$ Construed from Sumerian tales and new compositions, the Akkadian version of the Gilgameš Epic, already well-known from the beginning of the second millennium BCE, was

58 Ouyang and Proust, forthcoming.

59 For the third millennium, see, for example, the text ARET XX, 25, reverse 11, 9, a photo of which is accessible online <http://ebda.cnr.it/tablet/view/3115> (accessed on 13 Oct. 2020). Such textual additions may also be found in some first-millennium colophons. Or, occasionally, signs were added as the tablet was in the process of drying; see, for example, King 1914, 9, tablet 48 [Ki. 1904-10-9, 11]: 'After the tablet had partly dried, five lines were added by the scribe on a blank space on the Reverse above the colophon.' A photo of this tablet (which joins two other pieces) is visible at <https://cdli.ucla.edu/dl/photo/P394724.jpg $>$ (accessed on 8 Sept. 2020).

60 Leichty 1964, Hunger 1968.

61 Weidner 1944.

62 George 2003. 
standardized in later times. The most complete version comes from the library of Aššurbanipal's palace (seventh century BCE) and runs over twelve tablets arranged in a specific order. The colophons of each tablet indicate the number of the tablet in the series, and thus clay tablets could be arranged in a series like pages in a book.

\section{Clay tablets in archives and libraries}

Clay cuneiform tablets were usually kept in archives and libraries that were located in official buildings and private houses. Official archives were located in large organizations, palaces, and temples, which could also contain private archives. Private archives belonged to individuals and have usually been excavated in their houses; they often concern several generations of a family. Most of these archives were sorted though and weeded out from time to time in antiquity. ${ }^{63}$

In these archives, tablets were arranged on shelves or kept in baskets and coffers made of perishable materials that have not survived, though tablets were also kept in clay jars (Fig. 5).

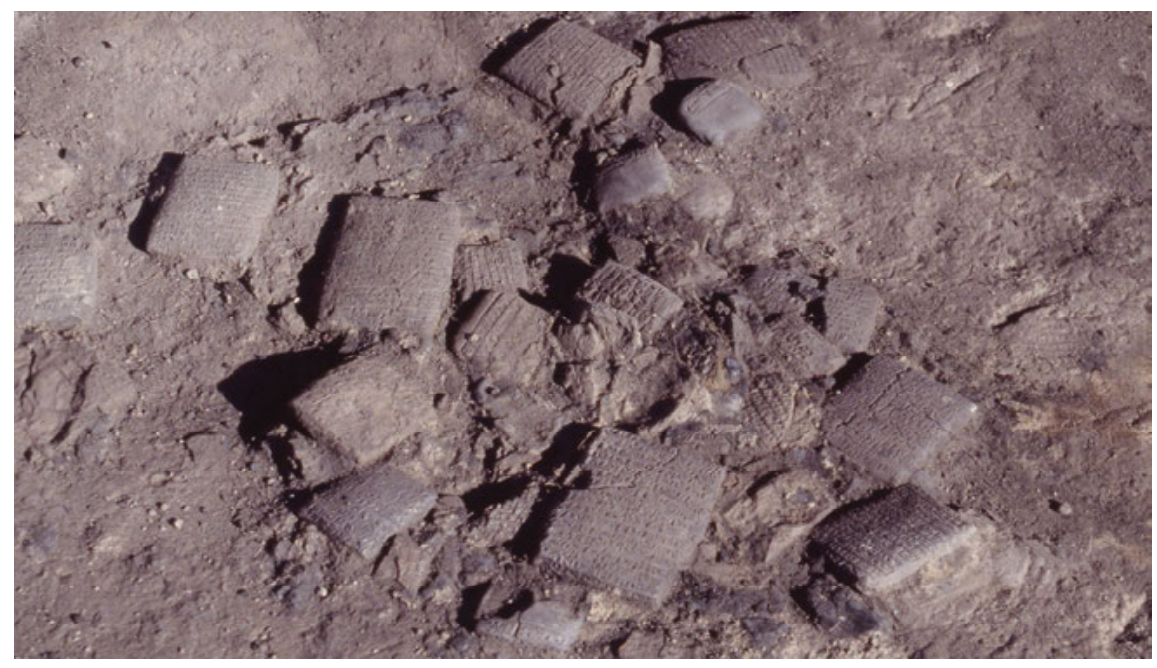

Fig. 5: Archive from a family of merchants, kept in a perishable container, Kültepe, nineteenth century BCE. () Kültepe Archaeological Mission, Archives.

63 Veenhof 1986, for example. 
Such containers, kept in specific rooms, were identified by a clay label. Archives could be arranged by owner, in dossiers dealing with the same affairs, or by text genre such as letters, legal texts, etc. ${ }^{64}$

Beside archives, other collections of texts have been found; these collections form real libraries that are mainly dedicated to sources produced in scholarly contexts. The libraries include texts dealing with divination, medicine, religion, technical matters, 'science', literature, and pedagogy, including, for example, lexical lists. Such libraries are attested from the second half of the second millennium, a period when most of the literary texts were canonized. The libraries have been unearthed in the houses of priests, diviners, or other scholars, but in later times more often in palaces and temples. ${ }^{65} \mathrm{King}$ Aššurbanipal (668-627) gathered in his palace at Nineveh one of the most important collections of cuneiform scholarly texts, more than 20,000 in number, which are now housed in the British Museum. In temples and palaces, tablets were stored in niches in the walls of specific rooms, near a courtyard giving enough light to read, or they were positioned on shelves along the walls. Cuneiform texts kept in archives and libraries have characteristics that are relevant to manuscripts.

\section{Conclusion}

The great majority of the cuneiform texts discovered so far were written on clay; the number of texts written on stone and metal is quite limited, and the number of texts written on other media (wood, leather, papyrus) is unknown since such organic materials have not survived. Clay is traditionally considered one of the media for epigraphical studies. Yet if we consider cuneiform tablets, they share many characteristics with manuscripts: they were written by hand and are thus unique; they were transportable; they could be enclosed in an envelope; they could bear annotations or drawings and be erased or recycled; they could also be grouped into books of a sort and arranged in archives and libraries.

In 2015, characteristics such as these led scholars at the Centre for the Study of Manuscript Cultures in Hamburg to propose a new and expanded definition of the word 'manuscript': 'a manuscript is an artefact planned and realised to provide surfaces on which visible signs are applied by hand; it is portable, self-

64 Archi 2015 or Michel 2018, among many others.

65 Clancier 2009. 
contained, and unique'. ${ }^{66}$ In fact, many written artefacts do not fit into the traditional categories that contrast manuscripts with epigraphy, with the result that such artefacts occupy a vast grey zone between these two categories.

Within the community of scholars who decipher cuneiform texts written on clay tablets, some scholars refer to their sources as manuscripts, and studies in cuneiform palaeography have flourished in recent decades. ${ }^{67}$ Such scholars, however, also often call themselves epigraphists. The name of the discipline itself, Assyriology, is built on 'Assyria', suggesting a very limited topic, but it actually refers to all texts written in cuneiform, embracing a great variety of languages such as Sumerian, Hurrian, and Hattic (three languages that do not belong to any known linguistic family), the Semitic language Akkadian and its dialects, Assyrian and Babylonian, as well as the Indo-European Hittite language. The word 'Assyriology' corresponds more generally 'to the study of ancient Mesopotamia and neighbouring regions through textual, archaeological and art historical approaches' ${ }^{68}$

A biography of François Thureau-Dangin (1872-1944) presents him as a 'French archaeologist, Assyriologist and epigrapher. He played a major role in the deciphering of Sumerian and Akkadian languages' ${ }^{69}$ In 2013, the Oriental Institute at the University of Chicago advertised a professorship in Assyriology as follows: 'Applications are welcome from scholars with a research focus in any period or subfield of Assyriology. The successful candidate should be able to teach a wide range of courses in Akkadian grammar, texts, and epigraphy and courses on Mesopotamian civilization and history.' Such terminology harks back to the early days of the discipline. ${ }^{70}$

How can we explain this double paradox, which consists of using the term 'epigraphist' for scholars working on cuneiform clay manuscripts, and the word

66 Lorusso et al. 2015.

67 Biggs 1973, 40, regrets the absence of studies dealing with cuneiform handwriting: 'in my opinion, the greatest problem in cuneiform palaeography is our lack of knowledge about the particular handwritings of the various scribal centers.' Among recent studies on this topic, see, for example, Devecchi et al. (eds) 2015.

68 Definition given by the International Association for Assyriology, <https://iaassyriology.com/ assyriology/> (accessed on 3 June 2020). In 1928, as part of his efforts to distance Turkey from the Arab world, Mustafa Kemal Atatürk replaced the Arabic-script Turkish alphabet with a Latin-script alphabet. In the same spirit, Assyriology is referred to as Sümeroloji in Turkey, because of attempts to claim an affiliation between Turkish and Sumerian.

69 <http://en.wikipedia.org/wiki/Fran\%C3\%A7ois_Thureau-Dangin> (accessed on 4 June 2013).

70 Thureau-Dangin 1896, 360, concerning tablets from Tello, mentions, for example, 'des documents épigraphiquement antérieurs'. 
'Assyriology' to depict a discipline partly linked to the decipherment of a great variety of languages?

The first archaeological explorations in Mesopotamia were carried out in the middle of the nineteenth century by French and British diplomats on the ruins of the Assyrian capitals: Nineveh, Khorsabad (ancient Dûr-Šarrukēn), and Nimrud (ancient Kalhu). These early excavators unearthed the remains of huge palaces built by the Assyrian kings of the first millennium BCE that were decorated with large reliefs on stone slabs, sometimes covered with cuneiform inscriptions. ${ }^{71}$ The first contact of European scholars with ancient cuneiform texts thus concerned royal inscriptions written in the Assyrian language and engraved on stone, hence the double designation of specialists of cuneiform texts as 'Assyriologists' and 'epigraphists', despite the fact that they mainly work on manuscripts as palaeographers do.

\section{Acknowledgements}

I would like to address my warmest thanks to Massimo Maiocchi and Piotr Michalowski who read and commented on this text, and to Richard Bishop who polished my English.

\section{References}

Albenda, Pauline (1991), 'Decorated Assyrian Knob-plates in the British Museum', Iraq, 53: 43-53. André-Leicknam, Béatrice and Christiane Ziegler (eds) (1982), Naissance de l'écriture. Cunéiformes et hiéroglyphes. Galeries nationales du Grand Palais 7 mai-9 août 1982, Paris: Éditions de la Réunion des Musées Nationaux.

Archi, Alfonso (2015), 'The Archives of Ebla', in Alfonso Archi (ed.), Ebla and Its Archives: Texts, History, and Society (Studies in Ancient Near Eastern Records, 7), Berlin: De Gruyter, 77-92.

Barnett, Richard D. (1976), Sculptures from the North Palace of Ashurbanipal at Nineveh, (668627 B.C.), London, British Museum Publications.

Bérenger, Marine (2018), 'Fonctions et usages des enveloppes de lettres dans la Mésopotamie des III et II mil. Av. J.-C. (2340-1595 av. J.-C.)', Épistolaire, 44: 25-43.

Biggs, Robert D. (1973), 'On Regional Cuneiform Handwritings in Third Millennium Mesopotamia', Orientalia, 42: 39-46.

Cartwright, Caroline and Jon Taylor (2011), 'Investigating Technological and Environmental Evidence from Plant Remains and Molluscs in Cuneiform Tablets', The British Museum Technical Research Bulletin, 5: 67-72.

Charpin, Dominique (2002), 'Esquisse d'une diplomatique des documents mésopotamiens', Bibliothèque de l'École des Chartes, 160/2: 487-511.

71 Larsen 1996. 
Charpin, Dominique (2008), Lire et écrire à Babylone, Paris: PUF.

Chiera, Edward (1938), They Wrote on Clay: The Babylonian Tablets Speak Today, Chicago: University of Chicago Press.

Clancier, Philippe (2005), 'Les scribes sur parchemin du temple d'Anu', Revue d'Assyriologie et d'archéologie orientale, 99: 85-104.

Clancier, Philippe (2009), Les bibliothèques en Babylonie dans la deuxième moitié du $1^{\text {er }}$ millénaire av. J.-C. (Alter Orient und Altes Testament, 363), Münster: Ugarit Verlag.

Clancier, Philippe (2011), 'Cuneiform Culture's Last Guardians: The Old Urban Notability of Hellenistic Uruk', in Karen Radner and Eleanor Robson (eds), The Oxford Handbook of Cuneiform Culture, Oxford: Oxford University Press, 752-773.

Cooper, Jerrold S. and Wolfgang Heimpel (1983), 'The Sumerian Sargon Legend', Journal of the American Oriental Society, 103: 67-82.

Devecchi, Elena, Gerfrid G. W. Müller and Jana Mynářová (eds) (2015), Current Research in Cuneiform Palaeography: Proceedings of the Workshop Organised at the 60th Rencontre Assyriologique Internationale, Warsaw 2014, Gladbeck: PeWe-Verlag.

Edzard, Dietz Otto (1997), Gudea and His Dynasty (The Royal Inscriptions of Mesopotamia, Early Periods, 3/1), Toronto: University of Toronto Press.

Faivre, Xavier (1995), 'Le recyclage des tablettes cunéiformes', Revue d'Assyriologie et d'archéologie orientale, 89: 57-66.

Fincke, Jeanette (2004), 'The Babylonian Texts of Nineveh', Archiv für Orientforschung, 50: 111149.

Finkel, Irving and Jonathan Taylor (2015), Cuneiform. London: British Museum Press.

Frahm, Eckart (2011), Babylonian and Assyrian Text Commentaries: Origins of Interpretation (Guides to the Mesopotamian Textual Record, 5), Münster: Ugarit Verlag.

Frahm, Eckart and Klaus Wagensonner (2019), 'Cuneiform Writing. Origins, History, Decipherment' in Agnete W. Lassen, Eckart Frahm and Klaus Wagensonner (eds), Ancient Mesopotamia Speaks: Highlights of the Yale Babylonian Collection (Yale University Publications in Anthropology), New Haven: Yale University Press, 23-44.

Friberg, Jöran (2007), A Remarkable Collection of Babylonian Mathematical Texts (Manuscripts in the Schøyen Collection. Cuneiform Texts, 1), New York: Springer.

George, Andrew (2003), The Babylonian Gilgamesh Epic: Introduction, Critical Edition and Cuneiform Texts, 2 vols, Oxford: Oxford University Press.

Gibson, McGuire and Robert D. Biggs (1977), Seals and Sealing in the Ancient Near East (Bibliotheca Mesopotamica, 6), Malibu: Undena Publications.

Heinrich, Ernst and Ursula Seidl (1967), 'Grundrisszeichnungen aus dem Alten Orient', Mitteilungen der Deutschen Orient-Gesellschaft, 98: 5-54.

Horowitz, Wayne (1988), 'The Babylonian Map of the World', Iraq, 50: 147-165.

Hunger, Hermann (1968), Babylonische und assyrische Kolophone (Alter Orient und Altes Testament, 2), Kevelaer: Butzon \& Bercker/ Neukirchen-Vluyn: Neukirchener Verlag des Erziehungsvereins.

Hunger, Hermann (1970), 'Das Archiv des Nabû-ušallim', Baghdader Mitteilungen, 5: 193-304. Jursa, Michael (2005), Neo-Babylonian Legal and Administrative Documents. Typology, Contents and Archives (Guides to the Mesopotamian Textual Record, 1), Münster: Ugarit Verlag.

King, Leonard W. (1914), Catalogue of the Cuneiform Tablets in the Kouyunjik Collection of the British Museum, Supplement, London: Trustees of the British Museum. 
Koch-Westenholz, Ulla (2000), Babylonian Liver Omens. The Chapters Manzāzu, Padānu and Pān tākalti of the Babylonian Extispicy Series mainly from Aššurbanipal's Library (Carsten Niebuhr Institute Publications, 25), Copenhagen: Museum Tusculanum Forlag.

Krebernik, Manfred (2001), Die Altorientalischen Schriftfunde, vol. 2 of Eva Strommenger (ed.), Ausgrabungen in Tall Bi'a/Tuttul (Wissenschaftliche Veröffentlichung der Deutschen Orient-Gesellschaft, 100), Saarbrücken: Saarbrücker Druckerei und Verlag.

Kupper, Jean-Robert (1998), Lettres royales du temps de Zimri-Lim (Archives royales de Mari, 28), Paris, ERC.

Larsen, Mogens T. (1996), The Conquest of Assyria: Excavations in an Antique Land, 1840-1860, London: Routledge.

Leichty, Erle (1964) 'The Colophon', in Robert D. Biggs and John A. Brinkman (eds), Studies Presented to A. Leo Oppenheim, Chicago: Oriental Institute, 147-155.

Lion, Brigitte and Cécile Michel (eds) (2016), Les écritures cunéiformes et leur déchiffrement, (Travaux de la maison René-Ginouvès, 4), $2^{\text {nd }}$ edn, Paris: Éditions Khéops [ $1^{\text {st }}$ edn: De Boccard, 2008].

Liverani, Mario (1996), 'Reconstructing the Rural Landscape of the Ancient Near East', Journal of the Economic and Social History of the Orient, 39: 1-41.

Lorusso, Vito et al. (2015), 'Searching for a Definition of “Manuscript”, Centre for the Study of Manuscript Cultures - Occasional Paper No. $1<\mathrm{http}$ ://www.manuscript-cultures.unihamburg.de/papers_e.html> (accessed on 3 June 2020).

Meek, Theophile J. (1935), Excavations at Nuzi: Volume III Old Akkadian, Sumerian, and Cappadocian Texts from Nuzi (Harvard Semitic Series, 10), Cambridge, MA: Harvard University Press.

Michalowski, Piotr (2011), Correspondence of the Kings of Ur: An Epistolary History of an Ancient Mesopotamian Kingdom (Mesopotamian Civilizations, 15), Winona Lake: Eisenbrauns.

Michel, Cécile (1995), 'Validité et durée de vie des contrats et reconnaissances de dette paléoassyriens', Revue d'Assyriologie et d'archéologie orientale, 89: 15-27.

Michel, Cécile (2001) Correspondance des marchands de Kanish (Littératures anciennes du Proche-Orient, 19), Paris: Éditions du Cerf.

Michel, Cécile (2008), 'La correspondance des marchands assyriens du XIXe s. av. J.-C. : de l'archivage des lettres commerciales et privées', in Laure Pantalacci (ed.), La lettre d'archive. Communication administrative et personnelle dans l'Antiquité proche-orientale et égyptienne (Topoi orient-occident, Suppl. 9), Le Caire: IFAO, 117-140.

Michel, Cécile (2018), 'Constitution, Contents, Filing and Use of Private Archives: The Case of the Old Assyrian Archives (19th century BC)', in Alessandro Bausi, Christian Brockman, Michael Friedrich and Sabine Kienitz (eds), Manuscripts and Archives: Comparative Views on Record-Keeping (Studies in Manuscript Cultures, 11), Berlin: De Gruyter, 43-70.

Michel, Cécile (2020a), 'Making Clay Envelopes in the Old Assyrian Period', in Fikri Kulakoğlu, Cécile Michel and Güzel Öztürk (eds), Integrative Approaches to the Archaeology and History of Kültepe-Kanesh, Kültepe, 4-7 August, 2017 (Kültepe International Meetings, 3; SUBARTU, 45), Turnhout: Brepols, 187-203.

Michel, Cécile (2020b), ‘Cuneiform Forgeries: A Long History from Antiquity to Today', in Cécile Michel and Michael Friedrich (eds), Fakes and Forgeries of Written Artefacts from Ancient Mesopotamia to Modern China (Studies in Manuscript Cultures, 20), Berlin: De Gruyter, 25-61.

Oelsner, Joachim (2003), 'Cuneiform Archives in Hellenistic Babylonia: Aspects of Content and Form', in Maria Brosius (ed.), Ancient Archives and Archival Traditions: Concepts of Record- 
Keeping in the Ancient World (Oxford Studies in Ancient Documents), Oxford: Oxford University Press, 284-301.

Ouyang, Xiaoli and Christine Proust (forthcoming), 'Place Value Notations in the Ur III Period: Marginal Numbers in Administrative Texts', in Karine Chemla, Agathe Keller and Christine Proust (eds), Cultures of computation and quantification, Cham: Springer.

Özgüç, Nimet and Önan Tunca (2001), Kültepe-Kaniš Mühürlü ve Yaıtlı kil bullalar. Sealed and inscribed clay bullae (Türk Tarih Kurumu yayınlarından, series 5, 48), Ankara: Türk Tarih Kurumu Basımevi.

Proust, Christine (2007), Tablettes mathématiques de Nippur (Varia Anatolica, 18), Istanbul: IFEA.

Radner, Karen (1995), 'The Relation between Format and Content of Neo-Assyrian Texts', in Raja Mattila (ed.), Nineveh 612 BC: The Glory and Fall of the Assyrian Empire; Catalogue of the 10th Anniversary Exhibition of the Neo-Assyrian Text Corpus Project, Helsinki, Helsinki University Press, 63-78.

Reade, Julian (2017), 'The Manufacture, Evaluation and Conservation of Clay Tablets Inscribed in Cuneiform: Traditional Problems and Solutions', Iraq, 79: 163-202.

Robert, Louis (1961), 'Les épigraphies et l'épigraphie grecque et romaine', in Charles Samaran (ed.) L'histoire et ses méthodes (Encyclopédie de la Pléiade, 11), Paris: Gallimard, 453497.

Robson, Eleanor (2001), 'The Tablet House: A Scribal School in Old Babylonian Nippur', Revue d'assyriologie et d'archéologie orientale, 95: 39-66.

Robson, Eleanor (2009), 'Mathematics Education in an Old Babylonian Scribal School,' in Eleanor Robson and Jacqueline Stedall (eds), The Oxford Handbook of the History of Mathematics, Oxford: Oxford University Press, 199-227.

Sauvage, Martin (1998), La brique et sa mise en œuvre en Mésopotamie des origines à l'époque achéménide (Travaux du Centre de Recherche d'Archéologie Orientale, Université de Paris I, 13), Paris, ERC.

Still, Bastian and Rieneke Sonnevelt (2020), 'On Sippar's Quay: Cuneiform Tablets with Aramaic Inscriptions from the Böhl Collection in Leiden', Zeitschrift für Assyriologie, 110: 94110.

Tadmor, Hayim and Shigeo Yamada (2011), The Royal Inscriptions of Tiglath-pileser III (744-727 $B C$ ) and Shalmaneser V (726-722 BC), Kings of Assyria (The Royal Inscriptions of the NeoAssyrian Period, 1), Winona Lake: Eisenbrauns.

Taylor, Jon and Caroline Cartwright (2011), 'The Making and Re-making of Clay Tablets', Scienze dell'Antichità, 17: 297-324.

Thureau-Dangin, François (1896), 'Les tablettes de Sargon l'ancien et de Naram-Sîn', Comptes rendus des séances de l'Académie des inscriptions et Belles-Lettres, 40/4: 355-361.

Thureau-Dangin, François (1912), Une relation de la huitième campagne de Sargon (714 av. J.-C.) (Textes cunéiformes, 3), Paris: Geuthner.

Veenhof, Klaas R. (ed.) (1986), Cuneiform Archives and Libraries. Papers read at the 30e Rencontre Assyriologique Internationale, Leiden 4-8 July 1983 (Uitgaven van het Nederlands Historisch-Archaeologisch Instituut te Istanbul, 57), Leiden: Nederlands HistorischArchaeologisch Instituut te Istanbul.

Veenhof, Klaas R. (2003), 'Archives of Old Assyrian Traders', in Maria Brosius (ed.), Ancient Archives and Archival Tradition: Concepts of Record-Keeping in the Ancient World (Oxford Studies in Ancient Documents), Oxford: Oxford University Press, 78-123. 
Veldhuis, Niek (1997), Elementary Education at Nippur: The Lists of Trees and Wooden Objects, $\mathrm{PhD}$ dissertation, University of Groningen.

Villard, Pierre (1984), 'Chapitre V, textes no. 535 à 627’, in Guillaume Bardet et al. (eds), Archives Administratives de Mari 1 (Archive royales de Mari, 23), Paris: ERC, 453-585.

Villard, Pierre (1997), 'L'éducations d’Aššurbanipal', Ktèma, 22: 135-149.

Walker, Christopher B. F. (1987), Cuneiform (Reading the Past, 3), London: Trustees of the British Museum.

Weidner, Ernst (1944), 'Die Astrologische Serie Enûma Anu Enlil (mit 12 Taflen)', Archiv für Orientforschung, 14: 172-195, 308-318.

Winter, Irene (1983), 'The Program of the Throneroom of Assurnasirpal II', in Prudence

O. Harper and Holly Pittman (eds), Essays on Near Eastern Art and Archaeology in Honor of Charles Kyrle Wilkinson, New York: Metropolitan Museum of Art, 15-32. 
